\title{
The presence of $s b o A$ and spaS genes and antimicrobial peptides subtilosin A and subtilin among Bacillus strains of the Amazon basin
}

\author{
Renata Voltolini Velho ${ }^{1}$, Ana Paula Basso ${ }^{1}$, Jeferson Segalin ${ }^{2}$, Luis Fernando Costa-Medina ${ }^{1}$ \\ and Adriano Brandelli ${ }^{1}$ \\ ${ }^{1}$ Laboratório de Bioquímica e Microbiologia Aplicada, Departamento de Ciência de Alimentos, \\ Instituto de Ciência e Tecnologia de Alimentos, Universidade Federal do Rio Grande do Sul, \\ Porto Alegre, RS, Brazil. \\ ${ }^{2}$ Unidade de Quimica de Proteinas e Espectrometria de Massas, Centro de Biotecnologia, \\ Universidade Federal do Rio Grande do Sul, Porto Alegre, RS, Brazil.
}

\begin{abstract}
This report demonstrates the usefulness of PCR for the genes spaS and $s b o A$ as a means of identifying Bacillus strains with a potential to produce subtilin and subtilosin A. One collection strain and five Bacillus spp. isolated from aquatic environments in the Amazon basin were screened by PCR using primers for sboA and spaS designed specifically for this study. The sequences of the PCR products showed elevated homology with previously described spaS and $s b o A$ genes. Antimicrobial peptides were isolated from culture supernatants and analyzed by mass spectrometry. For all samples, the mass spectra revealed clusters with peaks at $m / z 3300-3500 \mathrm{Da}$, corresponding to subtilosin $A$, subtilin and isoforms of these peptides. These results suggest that the antimicrobial activity of these strains may be associated with the production of subtilosin A and/or subtilin. The PCR used here was efficient in identifying novel Bacillus strains with the essential genes for producing subtilosin A and subtilin.
\end{abstract}

Keywords: Bacillus, bacteriocin, polymerase chain reaction, subtilin, subtilosin A.

Received: December 16, 2011; Accepted: October 8, 2012.

Many peptide antibiotics possess bactericidal, fungicidal and immunomodulatory activities and frequently occur as secondary metabolites produced by microorganisms. Among Bacillus species, some antimicrobial peptides are gene encoded and synthesized ribosomally while others are produced non-ribosomally by the multienzyme thiotemplate mechanism (Cotter et al., 2005).

Subtilosin A is the only anionic, circular antimicrobial peptide produced by wild strains of Bacillus subtilis (van Belkun et al., 2011). The production of mature subtilosin A requires the expression of eight ( $\mathrm{sboA-}$ albABCDEFG) of the nine genes identified in subtilosin A-producing strains of $B$. subtilis. These clustered genes are transcribed from a promoter residing upstream of the $s b o A$ gene and their products are involved in the posttranslational modification and processing of presubtilosin, secretion and immunity. The albABCDEFG genes are believed to constitute an operon that encodes the proteins that function in presubtilosin processing and subtilosin ex-

Send correspondence to Adriano Brandelli. Laboratório de Bioquímica e Microbiologia Aplicada, Departamento de Ciência de Alimentos, Instituto de Ciência e Tecnologia de Alimentos, Universidade Federal do Rio Grande do Sul, 91501-970 Porto Alegre, RS, Brazil. E-mail: abrand@ufrgs.br. port. The $s b o A$ gene encodes presubtilosin, a 43-aminoacid peptide (Zheng et al., 2000; van Belkun et al., 2011).

Subtilin is a lanthionine-containing peptide antibiotic (lantibiotic) very similar to nisin, which is the most important member of the group of linear lantibiotics and is used as a food preservative. The biosynthesis of this bacteriocin is based on the expression of ten genes that are organized in a gene cluster spaBTCSIFEGRK. The spaS gene encodes the prepeptide of subtilin in which amino acids are enzymatically modified by the products of genes $s p a B$ and spaC. The modified precursor is transported through the cytoplasmic membrane by the $\mathrm{ABC}$ transporter encoded by spaT, which appears to be associated with a membrane complex containing the enzymes $\mathrm{SpaB}$ and $\mathrm{SpaC}$ (Kiesau et al., 1997; Stein et al., 2003).

The Amazon basin is a source of enormous biological diversity for microorganisms with potential value for biotechnological applications (Chies et al., 2002). Some investigations have undertaken screening for useful microorganisms (Cladera-Olivera et al., 2004; Motta et al., 2004). The aim of this work was to screen for the subtilosin A and subtilin genes among Bacillus strains isolated from the intestine of Amazon basin fishes, using a simple, efficient PCR with specific primers for $s b o A$ and $s p a S$. 
Bacterial isolates were kindly provided by Dr. Spartaco Astolfi Filho (Universidade Federal do Amazonas, Manaus, AM, Brazil). The strains were Bacillus sp. P11 (GenBank accession no. DQ387864), Bacillus sp. P34 (AY962472) and Bacillus licheniformis P40 (AY962473), isolated from the fish Leporinus sp., and Bacillus sp. P7 (DQ387865) and Bacillus subtilis P45B (AY962474) isolated from Piaractus mesopotamicus intestines. B. subtilis ATCC 19659 and B. cereus ATCC 14579 were used as reference strains. The bacteria were maintained at $-21^{\circ} \mathrm{C}$ in BHI broth containing 20\% (v/v) glycerol and were cultivated in Triptone soy broth (TSB; Mast Diagnostics, Merseyside, UK) agar plates for $24 \mathrm{~h}$ at $37^{\circ} \mathrm{C}$ and then in TSB for $24 \mathrm{~h}$ at $37^{\circ} \mathrm{C}$ before use.

DNA was extracted from overnight cultures using the Promega Wizard SV Genomic DNA kit (Promega, Madison, WI, USA). The specific primers used for PCR amplification of the $s b o A$ and spaS genes were developed using Vector NTI primer design software (Invitrogen, Carlsbad, CA, USA). Primers sboA-f (5'-CATCCTCGATCACAG ACTTCACATG-3') and sboA-r (5'-CGCGCAAGTAGT CGATTTCTAACAC-3') were used to amplify a $734 \mathrm{bp}$ sboA fragment corresponding to the B. subtilis subtilosin gene cluster (AJ430547), whereas primers spas- $f$ (5'-TGTCATGGTTACAGCGGTATCGGTC-3') and spas- $r$ (5' - AGTGCAAGGAGTCAGAGCAAGGTGA3') were used to amplify a 566 bp spaS fragment corresponding to the B. subtilis subtilin gene cluster (U09819). Each $50 \mu \mathrm{L}$ of PCR mix contained $5 \mu \mathrm{L}$ of Taq buffer $10 \mathrm{x}$, $3 \mu \mathrm{L}$ of $25 \mathrm{mM} \mathrm{MgCl}_{2}, 0.4 \mu \mathrm{L}$ of $25 \mathrm{mM}$ dNTPs, $0.5 \mu \mathrm{L}$ of Taq polymerase ( $5 \mathrm{U} / \mathrm{mL}$; Invitrogen), $1.25 \mu \mathrm{L}$ of $20 \mu \mathrm{M}$ primer, $50 \mathrm{ng}$ of genomic DNA and $36.1 \mu \mathrm{L}$ of Milli-Q $\mathrm{H}_{2} \mathrm{O}$. PCR was done using a Mastercycler Personal thermocycler (Eppendorf AG, Hamburg, Germany) under the fol-

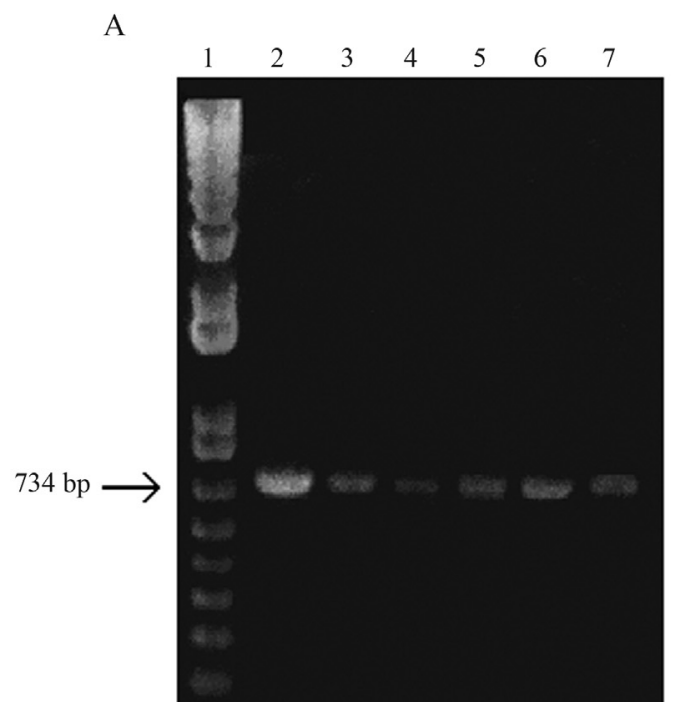

lowing conditions: denaturation for $1 \mathrm{~min}$ at $94^{\circ} \mathrm{C}$, annealing for $30 \mathrm{~s}$ at $50^{\circ} \mathrm{C}(\mathrm{sboA})$ or $55^{\circ} \mathrm{C}(\mathrm{spaS})$ and elongation for $1 \mathrm{~min}$ at $72^{\circ} \mathrm{C}$ for a total of 35 cycles for both subtilosin $\mathrm{A}$ and subtilin.

Electrophoretic analyses of the PCR products revealed $734 \mathrm{bp}$ and $566 \mathrm{bp}$ fragments for the $s b o A$ and $s p a S$ primers, respectively (Figure 1). No PCR products were observed for B. cereus ATCC 14579 that was used as a negative control (data not shown). The PCR products were sequenced in the ACTGene Laboratory (Centro de Biotecnologia, UFRGS, Porto Alegre, RS, Brazil) using an automatic sequencer (ABI-PRISM 3100 Genetic Analyzer; Applied Biosystems). The sequence data were collected using the software Data Collection ver. 1.0.1 (Applied Biosystems) and a BLAST algorithm was used to retrieve homologous sequences from GenBank (National Center for Biotechnonology Information) with the software CLUSTAL W v.1.8 (Thompson et al., 1994).

All sequences of the 734 bp fragments showed elevated homology (minimum identity: 98\%) with the gene encoding presubtilosin ( $s b o A$ ). Similarly, the sequences of the $566 \mathrm{bp}$ fragments had high homology (minimum identity: 97\%) with the gene encoding presubtilin (spaS). Differences in the sequences corresponded to silent mutations. The genes $s b o A$ and $\operatorname{spaS}$ are critical for production of the antimicrobial peptides subtilosin A and subtilin, respectively (Zheng et al., 2000; Stein et al., 2003).

Antimicrobial peptides were isolated as described by Kawulka et al. (2004). Samples concentrated in a vacuum centrifuge (SpeedVac SC100, Savant, USA) were dissolved in ethanol and analyzed by mass spectrometry in a MALDI-TOF mass spectrometer (MALDI-Micro MX PSD, Micromass, Manchester, UK) operated in reflection mode with a matrix of $\alpha$-cyano-4-hydroxycinnamic acid.

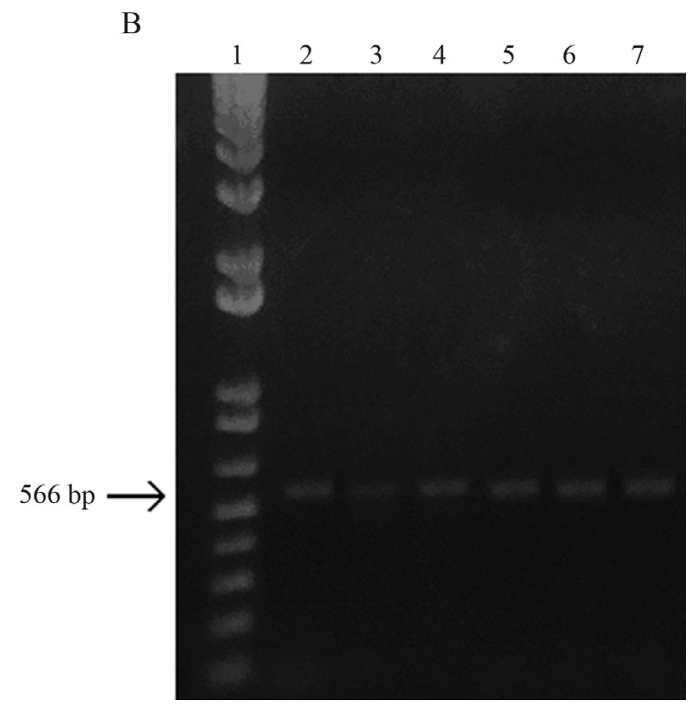

Figure 1 - PCR product profiles of the (A) sboA and (B) spaS genes. 1 - Molecular weight marker (1 kb PLUS, Invitrogen), 2 - Bacillus subtilis ATCC 19659, 3 - Bacillus sp. P7, 4 - Bacillus sp. P11, 5 - Bacillus licheniformis P40, 6 - Bacillus subtilis P45B, 7 - Bacillus sp. P34. Samples were run in 1\% agarose gels. 
Antimicrobial activity was determined by the disk diffusion method, essentially as described elsewhere (Motta et al., 2007). Listeria monocytogenes ATCC 7644 was used as the indicator organism.

The antimicrobial peptides were isolated from the cell-free culture supernatant of Bacillus spp. All strains showed antimicrobial activity against $L$. monocytogenes. The mass spectra revealed major peaks at $\mathrm{m} / \mathrm{z} 3300-3500$ Da (Figure 2), corresponding to subtilosin A, subtilin and isoforms of these peptides (Heinzmann et al., 2006; Abriouel et al., 2011). Typical $\mathrm{m} / \mathrm{z}$ values for subtilosin A (3399), subtilin (3319), succ-subtilin (3419) and its $\mathrm{K}^{+}$ adduct (3457) were observed in the spectra. A major peak at $\mathrm{m} / z 3442$ corresponding to ericin S (Bierbaum and Sahl, 2009) was also detected. Strain P7 presented a minor peak at $\mathrm{m} / \mathrm{z} 3347$, possibly associated with the recently discovered lantibiotic entianin (Fuchs et al., 2011). Strain P34 showed a more complex spectrum (Figure 2C), with some peaks that could not be attributed to known antimicrobial
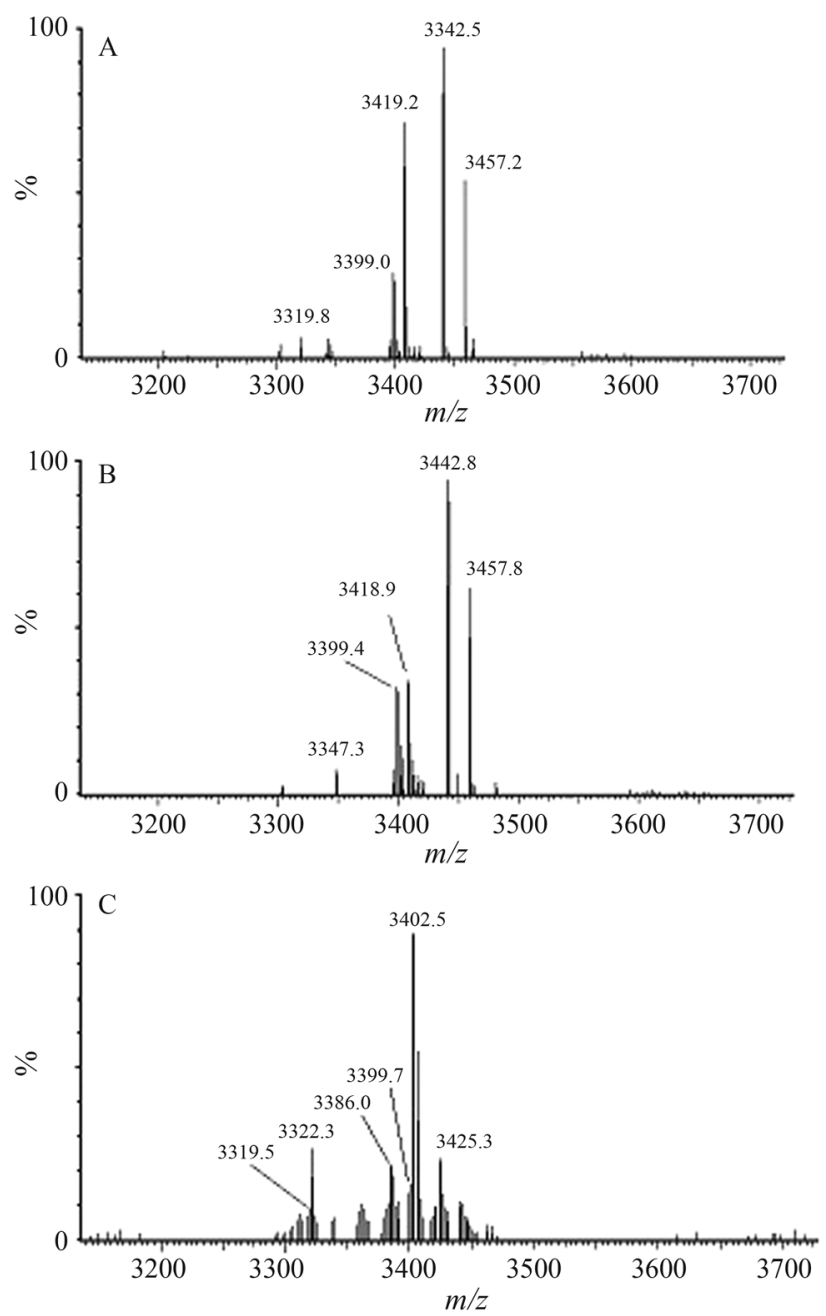

Figure 2 - Typical mass spectra of antimicrobial peptides extracted from culture supernatants of Bacillus spp. (A) B. subtilis ATCC 19659, (B) Bacillus sp. P7, (C) Bacillus sp. P34. peptides from Bacillus spp. These results agree with the fact that Bacillus may produce a diversity of antimicrobial peptides that vary according to the strain (Abriouel et al., 2011).

The results of this work indicate that PCR with specific primers for $s b o A$ and $s p a S$ is a valuable means of screening for Bacillus spp. and strains that produce subtilosin A and subtilin. With the exception of B. subtilis, the presence of subtilosin A had previously been reported only in a strain of B. amyloliquefaciens (Sutyak et al., 2008). Bacillus sp. P7 and P11 belong to the B. subtilis, $B$. amyloliquefaciens and B. velesensis cluster (Giongo et al., 2007), whereas strain P34 appears to be a novel Bacillus species (Motta et al., 2007). PCR-based methods are valuable tools for the rapid screening of class II bacteriocinproducing isolates in environmental samples (Yi et al., 2010). PCR has also been used to detect the bacteriocins nisin, pediocin and enterocin A in lactic acid bacteria isolated from traditional Thai fermented foods (Suwanjinda $e t$ al., 2007).

The continuous emergence of antibiotic resistance has led to increased interest in bacteriocins. These peptides are considered as the ultimate candidates for food preservation and some clinical applications because their range of activity is often limited and specific (Cotter et al., 2005). Like nisin, subtilosin A and subtilin have a proven track record of efficacy against L. monocytogenes (Stein et al., 2004; Burkard et al., 2007). Our results provide another option that should be investigated by the food industry.

\section{Acknowledgments}

This work was supported by Conselho Nacional de Desenvolvimento Científico e Tecnológico (CNPq).

\section{References}

Abriouel H, Franz CM, Omar NB and Galvez A (2011) Diversity and applications of Bacillus bacteriocins. FEMS Microbiol Rev 35:201-232.

Bierbaum G and Sahl HG (2009) Lantibiotics: Mode of action, biosynthesis and bioengineering. Curr Pharm Biotechnol 10:2-18.

Burkard M, Entian KD and Stein T (2007) Development and application of a microtiter plate-based autoinduction bioassay for detection of the lantibiotic subtilin. J Microbiol Meth 70:179-185.

Chies JM, Dias ACO, Maia HMM and Astolfi-Filho S (2002) BanAI a new isoschizomer of the type II restriction endonuclease HaeIII discovered in a Bacillus anthracis isolate from Amazon basin. FEMS Microbiol Lett 215:97-101.

Cladera-Olivera F, Caron GR and Brandelli A (2004) Bacteriocin-like substance production by Bacillus licheniformis strain P40. Lett Appl Microbiol 38:251-256.

Cotter PD, Hill C and Ross RP (2005) Bacteriocins: Developing innate immunity for food. Nat Microbiol 3:777-788.

Fuchs SW, Jaskolla TW, Bochnann S, Kötter P, Wichelhaus T, Karas M, Stein T and Entian KE (2011) Entianin, a novel 
subtilosin-like lantibiotic from Bacillus subtilis subsp. spizizenii DSM15029 ${ }^{\mathrm{T}}$ with high antimicrobial activity. Appl Environ Microbiol 77:1698-1707.

Giongo JL, Lucas FS, Casarin F, Heeb P and Brandelli A (2007) Keratinolytic proteases of Bacillus species isolated from the Amazon basin showing remarkable de-hairing activity. World J Microbiol Biotechnol 23:375-382.

Heinzmann S, Entian KD and Stein T (2006) Engineered Bacillus subtilis ATCC 6633 for improved production of the lantibiotic subtilin. Appl Microbiol Biotechnol 69:532-536.

Kawulka KE, Sprules T, Diaper CM, Whittal RM, Mckay RT, Mercier P, Zuber P and Vederas JC (2004) Structure of subtilosin A, a cyclic antimicrobial peptide from Bacillus subtilis with unusual sulfur to R-carbon cross-links: formation and reduction of R-thio-R-amino acid derivatives. Biochemistry 43:3385-3395.

Kiesau P, Eikmanns U, Gutowski-Eckel Z, Weber S, Hammelmann M and Entian KD (1997) Evidence for a multimeric subtilin synthetase complex. J Bacteriol 179:1475-1481.

Motta AS, Cladera-Olivera F and Brandelli A (2004) Screening for antimicrobial activity among bacteria isolated from the Amazon basin. Braz J Microbiol 35:307-310.

Motta AS, Cannavan FS, Tsai SM and Brandelli A (2007) Characterization of a broad range antibacterial substance from a new Bacillus species isolated from Amazon basin. Arch Microbiol 188:367-375.

Stein T, Heinzmann S, Kiesau P, Himmel B and Entian KD (2003) The spa-box for transcriptional activation of subtilin biosynthesis and immunity in Bacillus subtilis. Mol Microbiol 47:1627-1636.
Stein T, Düsterhus S, Stroh A and Entian KD (2004) Subtilosin production by two Bacillus subtilis subspecies and variance of the sbo-alb cluster. Appl Environ Microbiol 70:2349-2353.

Sutyak KE, Wirawan RE, Aroutcheva AA and Chikindas ML (2008) Isolation of the Bacillus subtilis antimicrobial peptide subtilosin from the dairy product-derived Bacillus amyloliquefaciens. J Appl Microbiol 104:1067-1074.

Suwanjinda D, Eames C and Panbangred W (2007) Screening of lactic acid bacteria for bacteriocins by microbiological and PCR methods. Biochem Mol Biol Educ 35:364-369.

Thompson JD, Higgins DG and Gibson TJ (1994) CLUSTAL W: Improving the sensitivity of progressive multiple sequence alignment through sequence weighting, position-specific gap penalties and weight matrix choice. Nucleic Acids Res 22:4673-4680.

van Belkun MJ, Martin-Visscher LA and Vederas JC (2011) Structure and genetics of circular bacteriocins. Trends Microbiol 19:411-418.

Yi H, Zhang L, Tuo Y, Han X and Du M (2010) A novel method for rapid detection of class IIa bacteriocin-producing lactic acid bacteria. Food Control 21:426-430.

Zheng G, Hehin R and Zuber P (2000) Mutational analysis of the sbo-alb locus of Bacillus subtilis: Identification of genes required for subtilosin production and immunity. J Bacteriol 182:3266-3273.

Associate Editor: Guilherme Corrêa de Oliveira

License information: This is an open-access article distributed under the terms of the Creative Commons Attribution License, which permits unrestricted use, distribution, and reproduction in any medium, provided the original work is properly cited. 